Provided for non-commercial research and educational use only. Not for reproduction or distribution or commercial use.

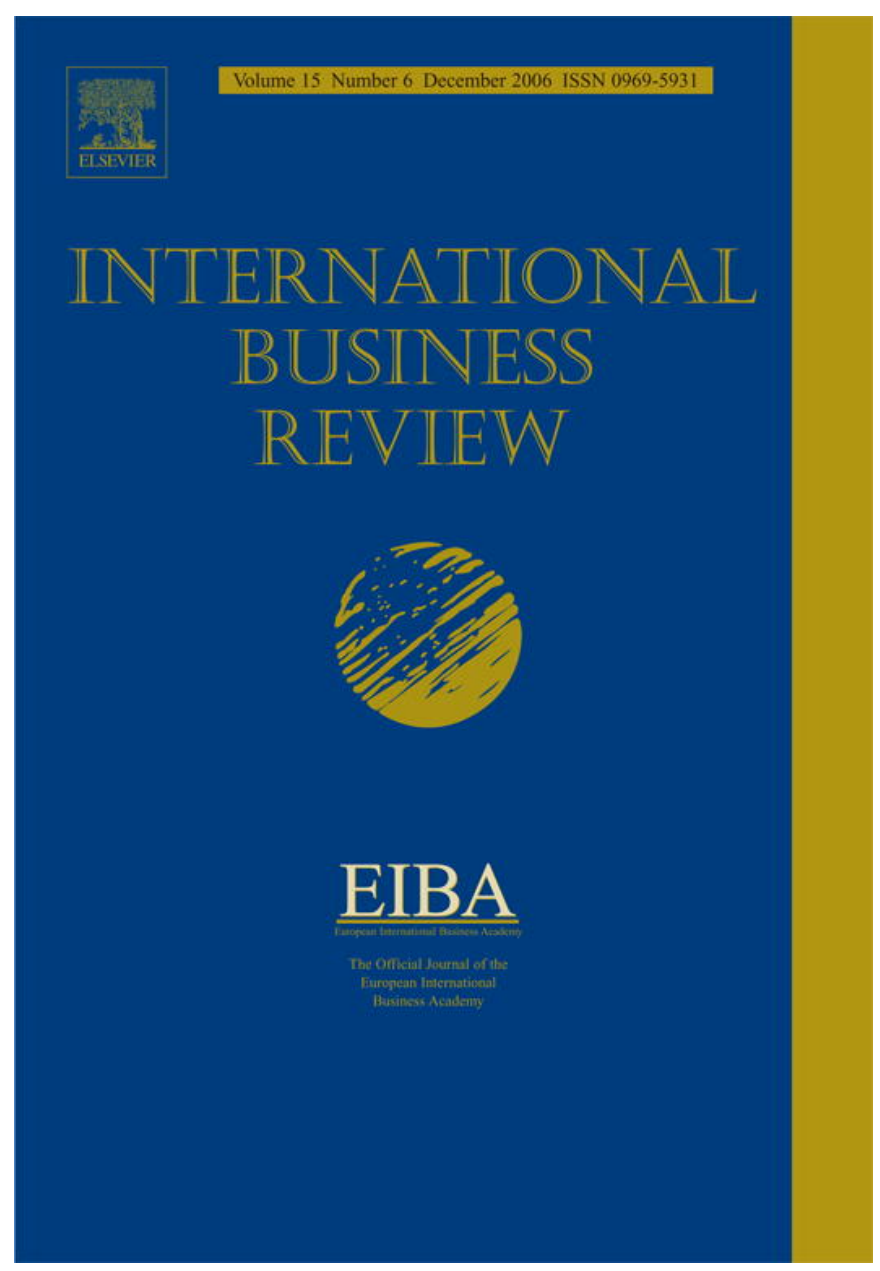

This article was originally published in a journal published by Elsevier, and the attached copy is provided by Elsevier for the author's benefit and for the benefit of the author's institution, for non-commercial research and educational use including without limitation use in instruction at your institution, sending it to specific colleagues that you know, and providing a copy to your institution's administrator.

All other uses, reproduction and distribution, including without limitation commercial reprints, selling or licensing copies or access,

or posting on open internet sites, your personal or institution's website or repository, are prohibited. For exceptions, permission may be sought for such use through Elsevier's permissions site at: 


\title{
Measuring internationalisation in the mobile telecommunications industry
}

\author{
Peter Curwen, Jason Whalley* \\ Department of Management Science, Strathclyde Business School, Graham Hills Building, 40 George St, Glasgow \\ G1 1QE, Scotland, UK
}

Received 24 November 2005; received in revised form 17 April 2006, 25 May 2006; accepted 18 September 2006

\begin{abstract}
The telecommunications industry is often described as being a global industry. However, the fact that it exists throughout the globe does not necessarily imply that its constituent companies are individually global in their operations. So far, little interest has been expressed in determining whether they are or are not in practice, but to do so requires that one first determine how this is to be measured. This article focuses on the measurement of internationalisation within the mobile telecommunications industry where the phenomenon can be most clearly identified. Drawing on the literature, four dimensions of internationalisation are initially identified and a database is constructed for the year ending 31 December 2005 that provides hard evidence in relation to these dimensions.

Analysis of the results reveals that just a handful of the companies in the sample can be considered to be meaningfully international when all four criteria are taken into account, and that Vodafone among them is best placed to describe itself as a global mobile operator although there are too many reservations for the term global to be seen as an appropriate label. The results highlight the complexity of internationalisation, with operators tending to do well on some of the criteria but not on others, and the paper illustrates how data availability influences the choice of criteria. Data availability also necessitates a trade-off between sample comprehensiveness and detail.

(C) 2006 Elsevier Ltd. All rights reserved.
\end{abstract}

Keywords: Internationalisation; Measurement; Mobile; Telecommunications

\footnotetext{
*Corresponding author. Tel.: + 44141548 4546; fax: + 441415526686 .

E-mail address: jason.whalley@strath.ac.uk (J. Whalley).
} 


\section{Introduction}

It is evident that the telecommunications industry is a global industry par excellence, not simply because every country in the world boasts telecommunications networks of various kinds but also because vast numbers of telephone calls and data streams originating in one country are terminated elsewhere in the world. The global nature of the telecommunications industry has attracted the interest of a small number of researchers. For example, Sarkar, Cavusgil, and Aulakh (1999) explored how market structure influenced internationalisation while Chan-Olmsted and Jamison (2001) concentrated on the rivalry that emerged between the global alliances that appeared at the start of the 1990s. Smith and Zeithaml (1998) adopted a different approach by highlighting the relationship between the domestic and international strategies of two Regional Bell Operating Companies, while Fang, Fridh, and Schultzberg (2004) investigated why the proposed merger between two Scandinavian incumbent operators failed. Largely overlooked has been internationalisation by the manufacturers of telecommunications equipment, though Steinbock (2002, 2005) has explored internationalisation from a standard setting perspective.

In contrast, this paper focuses on internationalisation within the mobile telecommunications industry. Unlike fixed-wire communications, mobile telecommunications is a growth sector and there are now more mobile than fixed lines (ITU, 2003). As the mobile telecommunications industry has grown, it has become an increasingly global phenomenon with mobile services of some kind available in almost every country in the world. The mobile telecommunications industry was initially highly fragmented, with service providers being national in scope. Many service providers were also joint ventures that combined local with foreign companies, with some countries reluctant to allow foreign control of a strategic industry such as telecommunications. The regulatory barriers to entry that fragmented the industry have been reduced, if not removed, through continued liberalisation and de-regulation since the mid-1980s. ${ }^{1}$ Liberalisation and de-regulation has been accepted to such an extent that most markets are now competitive (ITU, 2006). Whilst such changes are undoubtedly wide-ranging in nature, a key component has been the treatment of foreign investment. Bevan, Estrin, and Meyer (2004) found that in transitional economies, foreign direct investment was positively related to the quality of formal institutions while membership of the World Trade Organisation reduces the ability of host countries to discriminate between domestic and foreign sources of investment (Walden and Angel, 2005, p. 490). When taken together, these developments have largely removed the barriers to entry that fragmented the telecommunications industry.

It is not clear, however, whether the structure of the mobile telecommunications industry has changed as well. As only a handful of multinational service providers are identified by the UNCTAD (2005), an inevitable question that arises is how many multinational mobile operators exist? A second and related question is on what basis can such operators be identified? As a consequence, this paper sets out initially to identify a range of measurement criteria before commenting on the structure of the industry. To this end, the following section details the different ways through which internationalisation may be

\footnotetext{
${ }^{1}$ See, for example, Walden and Angel (2005) for a detailed discussion of telecommunications regulatory regimes globally as well as within the UK and European Union. An overview of the liberalisation process on a global basis in telecommunications as a whole can be found in, for instance, Braithwaite and Drahos (2000), Manner (2002) or Zacher (1996).
} 
measured, while the third section describes the methodology we have opted to use. The fourth section applies this methodology to the mobile operators that we have surveyed, while the fifth section explores which operator could be described as being the most internationalised within our sample. In the final section, the implications of our findings are discussed and conclusions drawn.

\section{Measuring internationalisation}

There is no shortage in the literature of suggestions as to how internationalisation may be measured. Dörrenbacher (2000) and Sullivan (1994) both suggest three broad categories of possible indicators of internationalisation: structural, performance and attitudinal. According to Dörrenbacher (2000, p. 120), structural indicators are those that provide a picture of the international entanglement of a company at a given moment in time. One example of such an indicator would be the number of countries in which the company is present, while another would be foreign assets as a percentage of total assets. The ratio between domestic and foreign employment is another structural indicator that is sometimes used to measure internationalisation.

Performance indicators measure how well the company is doing abroad. Dörrenbacher (2000, p. 120) identifies two indicators - turnover and operating income-while Sullivan (1994, p. 331) identifies an additional three indicators: R\&D intensity, advertising intensity and export sales as a percentage of total sales. Although Gerpott and Jakopin (2005) prefer the term 'outcomes' instead of performance, they also draw attention to foreign income as a percentage of total revenue.

Attitudinal indicators focus on the relationship between the home country of the internationalising company and its overseas operations. One measure is the amount of international experience that senior managers have, while another is the psychic dispersion of the international operations of a company (Sullivan, 1994, p. 332). One way to measure international experience is simply to count the number of years that senior management have lived abroad, though Dörrenbacher (2000) offers another, based on Perlmutter (1969) who identified three different types of headquarter/subsidiary relation: ethnocentric, polycentric and geocentric.

The notion of psychic distance was popularised by Johanson and Vahlne (1977). They argued that internationalisation is incremental, with companies initially favouring those countries that were closest to the home country before entering markets that were more distant. Kogut and Singh (1988) describe a methodology that uses Hofstede (1980) to rank countries relative to a given country. Perhaps a more straightforward way of determining psychic dispersion is to use the ten zones identified by Ronen and Shenkar (1985). Countries are grouped into ten zones on the basis of their attitudinal similarities. A company with international operations in five of these zones would, according to Sullivan (1994), have a psychic dispersion indicator score of 50 per cent.

The use of individual indicators provides an incomplete picture of internationalisation. For example, a company may have a presence in 20 different countries but these may only account for a fraction of its revenues or employees. As a consequence, some authors have sought to develop composite indices of internationalisation that combine several hitherto separate criteria. For example, Ietto-Gillies (1998) proposed a composite index that combines the ratio of foreign to total assets, sales and employment with a measure of how many countries the company could be present in if it so wished. UNCTAD (2005) divides 
these into two separate measures of internationalisation: a transnationality index (TNI) and an internationalisation index (II). The former of these is the average of the ratio of foreign to total assets, sales and employment while the latter is calculated by dividing the number of foreign affiliates by the number of all affiliates. Although these indices are intuitively attractive, it is worth noting that they do not control for country size. Hassel, Höpner, Kurdelbusch, Rehder, and Zugehör (2003, p. 721) are not alone in arguing that large companies from small countries will have a greater share of their activities overseas. The inclusion of such companies will distort any index that is calculated.

Sullivan (1994) combines five different performance criteria with two structural and two attitudinal measures into a composite index of internationalisation. The inherent difficulties of identifying relevant measurement criteria, and then combining them into a composite index, is illustrated by the subsequent exchange between Ramaswamy, Kroeck, and Renforth (1996) and Sullivan (1996). Ramaswamy et al. (1996) argued that the composite index proposed by Sullivan (1994) did not take into account the full complexity of internationalisation, with Sullivan (1996) responding, predictably, that they had misunderstood his original article.

Although the literature does provide a wide array of possible ways through which internationalisation could be measured, some are easier to implement than others. In particular, the availability of data influences which of the measures are feasible and which are not. By no means do all mobile operators describe their international operations in detail. As a consequence, it is often hard to determine the exact size of the investment or how many subscribers the international operation has in any particular year. In addition, the data can also be inconsistent between years, not least because operators restate their accounts to reflect the sale and purchase of businesses. This complicates any attempt to undertake a longitudinal analysis of internationalisation. One way to counter such inconsistency is to opt for data that are published regularly at both the individual investment and parent company level.

The aggregation of data is particularly problematic. When data are aggregated by line of business or geographical region, the performance of individual international investments is obscured. For example, although UNCTAD (2005) identifies France Télécom as being the second-most-internationalised telco, its reliance on France and the UK for mobile subscribers, and hence revenues, is hidden. Moreover, the choice of the parent company as the unit of analysis will obscure the internationalisation of any telecommunications subsidiaries. UNCTAD (2005) identifies nine telcos as being among the top 100 nonfinancial transnational corporations, but two-Hutchison Whampoa and Vivendi Universal-are overlooked and classified as 'diversified'.

The performance of individual investments is also obscured when partially-owned operations are consolidated with those that are wholly-owned. Financial data are frequently aggregated and consolidated with the result that there is insufficient detail to determine the revenues and profits of specific investments. Daßler, Parker, and Saal (2002) and Gerpott and Jakopin (2005) are only able to conduct their financial analyses of operators because they limit their samples to American, European and Japanese companies whose financial reporting requirements are comparatively onerous and thus provide relatively detailed data. The availability of financial data highlights the choice that needs to be made between being comprehensive on the one hand and being detailed on the other. Although being comprehensive increases the number of companies included within the index, and thus provides a better picture of internationalisation across the industry, it 
does so at the expense of detail. In contrast, greater detail provides a richer understanding of internationalisation but for fewer companies. In this paper, a more comprehensive approach has been adopted. Through doing so, the analysis will include as many internationalised mobile operators as possible and thus provide a fuller picture of the industry's structure.

\section{Methodology}

As a consequence of the limited global availability of data and the inherent inconsistency of much of what is available, four measures of internationalisation are adopted here. The first of these is the number of countries in which the mobile operator has invested, while the second is the psychic dispersion of these investments. Although Dunning (1993) and Root (1987) among others demonstrate the range of potential entry models that are available to an internationalising company, to be included in the country tally the presence must involve an investment in an operational mobile telecommunications network. This means that arrangements such as international roaming or brand franchising are excluded as they do not provide a sufficient degree of investment to merit inclusion. The third measure is the number of proportionate subscribers, while the fourth is the dispersion of those subscribers by region. These dimensions require clarification before we can proceed on to describing the extent of internationalisation within the mobile sector.

To be included in the analysis, the internationalising mobile operator must be present in at least three countries ${ }^{2}$ - a term used here to encompass any areas such as islands or territories that are self-governed and have their own telecoms licensing regulators. For most of the 34 companies identified on this criterion, this includes its domestic country plus at least two other countries. However, two of the companies-Investcom and Millicom International - are based in countries in which they do not operate. Where the company has multiple investments in the same country, only a single presence is recorded (although the subscribers for all networks are aggregated). Subject to that proviso, each equity stake, regardless of its size, is recorded as a single presence in a country. However, although each is accorded the same weighting or status when determining the number of countries in which a company is present, the size of the stake is adjusted for when calculating the associated number of subscribers (see below). ${ }^{3}$ Furthermore, a presence is recorded only when a network has been rolled out and is attracting subscribers; the mere acquisition of a licence is not counted.

Determining the exact number of countries in which a company is present is complicated by the use of holding companies in the telecommunications industry. It may be asked whether, if an operator has invested in a holding company, this should be counted as a

\footnotetext{
${ }^{2}$ This definition is necessarily somewhat arbitrary, but it would be equally arbitrary to draw the line at any other number and three has the significant merit of achieving a worthwhile size for the sample of countries under consideration. As can be seen in Table 1, raising the threshold to four would only reduce the sample by two. However, certain operators that technically reach the required sample size have been omitted: for example, SBC Communications because its international assets are essentially via a 7.9 per cent stake in América Móvil which appears in the table and Russia's Altimo because the ownership of some of its alleged assets are subject to ongoing court cases.

${ }^{3}$ The size of a stake is a very unreliable guide to the associated number of proportionate subscribers, and hence even very small stakes should not be excluded as is sometimes argued. For example, Vodafone's 3.3 per cent stake in China Mobile (Hong Kong) yielded 6.7 million proportionate subscribers in 2005.
} 
single investment or whether the holding company's individual subsidiary investments should also be included. The approach adopted here is to count all such investments as it is generally impossible to determine the extent of any influence exercised by partners in a joint venture and all may reasonably be assumed to be active partners unless they specify that the holding is purely for investment purposes. The same principles apply to the holding of stakes in other operators. ${ }^{4}$ Although it is possible to argue that a minorityowned subsidiary of a minority-owned operator should not be counted as a country presence due to the indirect nature of the stake, it may reasonably be counter-argued that the strategy being pursued is precisely to gain a presence in a spread of countries via this method rather than to attempt to buy direct stakes in tightly-held companies at exorbitant prices.

Once the country presence of a mobile operator has been determined, it is then possible to calculate its psychic dispersion. Ronen and Shenkar (1985) identify nine zones-Near Eastern, Nordic, Germanic, Arab, Anglo, Latin European, Latin American, Far Eastern and Independent. As these nine zones contain 46 countries between them, it is possible to add a tenth zone - Other - that allows a company's presence in all other markets to be noted. The methodology proposed by Sullivan (1994, p. 340) for calculating psychic dispersion can potentially be adopted with each zone equating to 10 per cent psychic dispersion. As the intention is to examine the psychic dispersion of the international operations of each of the mobile telcos, the home country should not be included in the analysis. Thus, if the mobile telco has international operations in five out of the ten zones, it would have a psychic dispersion score of 50 per cent.

The third dimension of internationalisation that we include in our analysis is the number of subscribers controlled by a mobile operator. To be included within the analysis, the company must control at least three million proportionate subscribers. ${ }^{5}$ At this point it is accordingly necessary to differentiate between 'gross' and 'proportionate' subscribers. Gross subscribers comprise all of the mobile subscribers to which a company can lay claim, either in its domestic market or based upon it having an investment in a foreign operator. As no account is taken of the size of the stake, the company simply claims all of the subscribers generated by its various investments for itself.

In contrast, proportionate (or equity) subscriber figures do take into account the size of the equity stake held. For example, if one telco owns a 50 per cent stake in another company that has two million subscribers, the proportionate subscriber figure that it can claim is one million. Since gross subscriber figures seriously inflate the number of subscribers controlled by a typical mobile operator, and thus distort the size of its revenue stream and profitability, we have opted to use proportionate subscriber figures throughout our analysis.

As noted, calculating proportionate subscriber levels is, however, far from straightforward. In the first place, it is often unclear exactly how many subscribers a mobile

\footnotetext{
${ }^{4}$ The obvious drawback to including indirectly-held stakes is that it superficially involves an element of doublecounting - that is, the same subscribers end up being attributed to two or more operators. However, the purpose of this paper is to examine the international operations of individual operators, not of operators as a whole, and hence this drawback is not relevant.

${ }^{5}$ Although this number is necessarily arbitrary, it has one major advantage in that it avoids the problems of making comparisons that would otherwise arise with operators such as Cable \& Wireless and Digicel which have large numbers of networks but where most of them yield very small numbers of proportionate subscribers.
} 
operator actually has, with the figure provided by the company often not agreeing with that produced by regulators, consultancies and Internet websites. ${ }^{6}$ Wherever possible, a company's own figures are used, but in many cases recourse has been had to other sources such as regulatory bodies. Related to this is a second complicating factor, namely that the exact size of some equity investments is unknown due to the presence of contradictory information in the public domain. In other words, it is not clear whether the size of the stake held is $X$ or $Y$ per cent. ${ }^{7}$

A third complicating factor is the presence of holding companies. Not only does the presence of holding companies ensure that another layer of ownership and subscriber data needs to be identified, but it also gives rise to the temptation to assume, incorrectly, that the holding company controls all of its subscribers. In practice, as Curwen (2005) notes, this is not always the case. For example, Vivo is a Brazilian-based joint venture that is owned 50/50 by Telefónica and Portugal Telecom. Hence, it is widely assumed that the gross and proportionate subscribers of this joint venture should be equally divided between the two parent companies. However, Vivo does not wholly own its various subsidiaries in Brazil. As a consequence, the proportionate number of subscribers that either Telefónica or Portugal Telecom could lay claim to in 2005 was significantly less than the number implied by a simple two-way division of the published subscriber numbers. A further problem can arise simply from failure to specify whether it is holding company or subsidiary that is being measured. Thus, for example, all mentions of Turkey's dominant mobile incumbent, irrespective of source, refer without fail to 'Turkcell'. What is never mentioned - usually because the writer is ignorant of the distinction - is that there is a parent, Turkcell Holding, and a half-owned operating subsidiary, Turkcell. Readers are evidently expected to know intuitively which is relevant.

Fourthly, around the turn of the millennium, several incumbent fixed-wire telcos formed specialised mobile subsidiaries that were subsequently part-floated on a stock exchange, possibly as a means of creating value for shareholders or possibly to create a currency in the form of the shares of the subsidiary that could be used to fund future acquisitions. One such company was Telecom Italia Mobile while another was Telefónica Móviles. However, when such companies were being formed, their parents did not necessarily transfer all of their mobile investments to the specialised mobile holding company. As a consequence, the mobile portfolio of the parent company often was, and sometimes still remains, larger than that held by the subsidiary. This is recognised through our unit of analysis being the parent company and not its mobile subsidiary. ${ }^{8}$

Once the proportionate subscribers for each of the 34 companies included in our analysis were calculated, it was possible to re-work the figures so that the geographical dispersion of

\footnotetext{
${ }^{6}$ By no means all companies provide subscriber data, and there is no universally accepted standard for reporting subscriber numbers. For example, companies often differ in how long they count a subscriber as 'active' after making or receiving the last recorded phone call or text message.

${ }^{7}$ Ownership of networks, especially in countries such as Russia, is a matter that is frequently brought before the law courts. Partly for this reason - it is anyway strictly a financial investor not a telco-Altimo (Alfa Telecom) has been excluded. For companies used in the sample, all ownership data have been carefully cross-checked and account taken of the position pending the outcome of any outstanding cases before the courts.

${ }^{8}$ This paper is, so far as we are aware, unique in adopting this approach. As it happens, the current popularity of buying back floated shares in mobile subsidiaries - cf. France Télécom/Orange, Deutsche Telekom/T-Mobile, Telefónica/Telefónica Móviles and Telecom Italia/TIM - means that NTT is now the only major operator with a significant public holding in its mobile subsidiary (although BT does not own one at all).
} 
subscribers was highlighted. Such an approach draws on the 'triad' analysis of Rugman (2005) which examined the sales of the largest 500 multinational enterprises and concluded that most multinationals are in fact regional and not globally focused. Recognising the regulatory and commercial differences that occur across the global mobile telecommunications industry, seven regions were identified: Western Europe, Eastern Europe, the Middle East, Asia, Central and South America, North America and Africa. ${ }^{9}$ The domestic markets of each of the 34 companies covered in the analysis were also identified. Together this enabled the percentage of proportionate subscribers accounted for by the company's domestic market and each region to be ascertained.

\section{Internationalisation}

The following sub-sections examine internationalisation within the mobile telecommunications sector from four different perspectives. The first sub-section concentrates on the number of countries and regions in which the 34 mobile operators that we have identified were present at the end of 2005, while the second sub-section focuses on the psychic dispersion of these countries. In contrast, in the third and fourth sub-sections, the focus is on the number of proportionate subscribers that each of the 38 companies controlled and their distribution across the seven regions that we have identified.

\subsection{Number of countries}

Drawing on Table 1, it is possible to make a series of observations regarding the number of countries in which mobile operators were invested at the end of 2005. The first observation is that the 364 entries are divided up in a somewhat unexpected manner ${ }^{10}$. One would intuitively expect international operators to be found predominantly in the most developed parts of the world and, in practice, Western Europe does loom large with 95 entries. By way of contrast, North America is largely the preserve of domestic operatorsonly Deutsche Telekom has an independently-owned network. What is really surprising is that Africa accounts for a further 88 entries, far more even than Asia. What this suggests, inter alia, is that Asian operators prefer to stick to their own region ${ }^{11}$ while the large number of African countries, combined with their general state of under-development, has presented opportunities for telcos wishing to establish their international credentials.

The second observation is that whereas the 34 companies surveyed were collectively invested in 364 countries, these investments were not at all evenly spread among the 34 companies. The most internationalised companies were Vodafone and France Télécom

\footnotetext{
${ }^{9}$ The attribution of countries to regions is covered in the footnotes to Table 2 . This is largely based upon simple geography-for example, Egypt is allocated to Africa whereas it has been argued in private correspondence that Egypt should be allocated to the Middle East on socio-political grounds even though this argument cannot strictly be said to apply to areas south of Luxor. The issue of what is meant by 'Europe', and how it should be divided between East and West, is becoming increasingly problematic, and many countries have recently had to be switched from east to west, but for now, fortunately, the consequences of Turkey becoming an EU member state need not concern us. Equally, a country such as Russia clearly falls into more than one geographic zone but it would be far too complicated to divide it up between regions.

${ }^{10}$ For further details see Curwen and Whalley (2004).

${ }^{11}$ NTT DoCoMo was the only Asian operator actively to seek an international footprint outside Asia and its tribulations overseas have done little to stimulate anyone else to follow suit although it is itself beginning to show signs of renewed interest.
} 
Table 1

Presence in countries (31 December 2005)

\begin{tabular}{|c|c|c|c|c|c|c|c|c|}
\hline \multirow[t]{2}{*}{ Company } & \multirow{2}{*}{$\begin{array}{l}\text { Number } \\
\text { of } \\
\text { countries }\end{array}$} & \multicolumn{7}{|c|}{ Number of countries by region } \\
\hline & & $\begin{array}{l}\text { Western } \\
\text { Europe }^{\mathrm{a}}\end{array}$ & $\begin{array}{l}\text { Eastern } \\
\text { Europe }^{b}\end{array}$ & $\begin{array}{l}\text { Middle } \\
\text { East }^{\mathrm{c}}\end{array}$ & Asia $^{\mathrm{d}}$ & $\begin{array}{l}\text { Central and } \\
\text { South } \\
\text { America }^{\mathrm{e}}\end{array}$ & $\begin{array}{l}\text { North } \\
\text { America }^{\mathrm{f}}\end{array}$ & Africa \\
\hline Vodafone $\mathrm{e}^{\mathrm{g}}$ & 32 & 16 & 2 & - & 6 & - & 1 & 7 \\
\hline France Télécom ${ }^{\mathrm{h}}$ & 27 & 11 & 2 & 1 & 1 & 2 & - & 10 \\
\hline Telefónica ${ }^{\mathrm{i}}$ & 25 & 2 & 1 & - & 4 & 14 & - & 4 \\
\hline MTC (incl. Celtel) & 18 & - & - & 4 & - & - & $\longrightarrow$ & 14 \\
\hline TeliaSonera & 17 & 7 & 3 & 4 & 2 & - & - & 1 \\
\hline Millicom International & 16 & - & - & - & 4 & 5 & - & 7 \\
\hline Hutchison Whampoa & 15 & 6 & - & 1 & 7 & - & - & 1 \\
\hline Telenor & 15 & 5 & 3 & - & 7 & - & - & - \\
\hline Tele $^{\mathrm{j}}$ & 15 & 13 & 2 & - & - & - & - & - \\
\hline América Móvil & 14 & - & - & - & - & 13 & 1 & - \\
\hline Deutsche Telekom $^{\mathrm{k}}$ & 14 & 8 & 4 & - & - & - & 1 & 1 \\
\hline Orascom & 14 & - & - & 2 & 7 & - & - & 5 \\
\hline Etisalat & 11 & - & - & 3 & - & - & - & 8 \\
\hline MTN & 10 & - & - & - & - & - & - & 10 \\
\hline TDC & 10 & 9 & - & 1 & - & - & - & - \\
\hline Investcom & 8 & 1 & - & 2 & - & - & - & 5 \\
\hline Portugal Telecom & 8 & 1 & - & - & 2 & 1 & - & 4 \\
\hline Telekom Malaysia & 8 & - & - & - & 6 & - & - & 2 \\
\hline NTT & 7 & - & - & - & 7 & - & - & - \\
\hline OTE & 7 & 1 & 5 & 1 & - & - & - & - \\
\hline Singapore Telecom & 7 & - & - & - & 7 & - & - & - \\
\hline Sprint Nextel & 7 & - & - & - & - & 5 & 2 & - \\
\hline Telecom Italia & 7 & 1 & - & 1 & - & 5 & - & - \\
\hline Turkcell Holding & 7 & - & 2 & 4 & 1 & - & - & - \\
\hline Mobile TeleSystems & 6 & - & 3 & - & 3 & - & - & - \\
\hline Alltel & 5 & 2 & - & - & - & 2 & 1 & - \\
\hline Telekom Austria & 5 & 3 & 2 & - & - & - & - & - \\
\hline Verizon Comms & 5 & 1 & - & - & - & 2 & 2 & - \\
\hline Vivendi Universal $^{1}$ & 5 & 1 & - & - & - & - & - & 4 \\
\hline Vodacom & 5 & - & - & - & - & - & - & 5 \\
\hline $\mathrm{O}_{2}$ & 4 & 4 & - & - & - & - & - & - \\
\hline VimpelCom & 4 & - & 2 & - & 2 & - & - & - \\
\hline KPN & 3 & 3 & - & - & - & - & - & - \\
\hline SK Telecom & 3 & - & - & - & 3 & - & - & - \\
\hline Total & 364 & 95 & 31 & 24 & 69 & 49 & 8 & 88 \\
\hline
\end{tabular}

${ }^{a}$ Western Europe includes the 25 EU current member states plus residual Western Europe.

${ }^{\mathrm{b}}$ Eastern Europe includes the Balkans, Belarus, Moldova, Russia and the Ukraine.

${ }^{\mathrm{c}}$ The Middle East includes the Arabian peninsula, Armenia, Azerbaijan, Cyprus (N), Georgia and Turkey.

${ }^{\mathrm{d}}$ Asia includes Kazakhstan, Australia and New Zealand.

${ }^{\mathrm{e}}$ Central and Southern America plus most of the Caribbean.

${ }^{\mathrm{f}}$ North America constitutes Canada, Puerto Rico and the USA.

${ }^{g}$ Network Partnership Agreements are not included within Vodafone's total.

${ }^{\mathrm{h}}$ Trading mostly as Orange, a wholly-owned subsidiary. Those French overseas territories where Orange is present are counted separately and not included within the total for France.

${ }^{i}$ Telefónica Móviles, a majority-owned subsidiary, owns and operates almost all of the networks.

${ }^{\mathrm{j}}$ MVNOs are included in Tele2's total as some investment is required before they can become operational.

${ }^{\mathrm{k}}$ Trading mostly as T-Mobile, a wholly-owned subsidiary.

${ }^{1}$ Poland is not counted as Vivendi has recently been adjudged not to have legal rights to its claimed assets there. 
with a presence in 32 and 27 countries, respectively, while the least internationalised companies were KPN and SK Telecom with a presence in three.

A third observation is that the 15 companies with a presence in at least 10 countries collectively accounted for 253 of the 364 investments. It may also be observed that the top five companies had a collective presence in 119 locations. In other words, the top five companies accounted for almost one-third of the listed countries, and the top 14 companies for over two-thirds. It is worth noting here that the top three companiesVodafone, France Télécom and Telefónica-were present in significantly more countries than the fourth-ranked, MTC, which was present in just 18. However, it may be also noted that Cable \& Wireless had, inter alia, stakes in a large number of (mostly) small Caribbean networks in 2005 but too few subscribers to qualify for the sample and that MTC only operated six networks in 2004 so it appears to be closing fast on the top two.

A related observation is that the investments of a significant proportion of the companies were numerically concentrated in a single region at the end of 2005. Altogether, 17 companies had two-thirds or more of their investments within a single region. Those companies which had concentrated their investments in Western Europe were KPN, $\mathrm{O}_{2}$, TDC and Tele2, while OTE was focused on Eastern Europe, NTT, Singapore Telecom, SK Telecom and Telekom Malaysia on Asia, América Móvil, Sprint Nextel and Telecom Italia on Central and South America and Etisalat, MTC, MTN, Vivendi and Vodacom on Africa.

\subsection{Psychic dispersion}

It is immediately evident that the geographical basis for the allocation of networks used in Table 1 does not accord all that closely with the concept of psychic dispersion which groups countries according to their cultural affinity, the argument being that companies seeking to internationalise may well prefer to go first to foreign countries that are culturally close - that is, in the same zone - in order to learn how to operate overseas before moving on elsewhere. Hence, the greater the number of zones in which they operate at any point in time, the greater is the degree of internationalisation achieved. However, the 10-zone division referred to previously is problematic when applied to mobile telecommunications as only 46 countries are identified in the nine zones excluding 'Other', and only 22 of the 34 mobile operators listed in Table 1 are to be found with a home base among the 46, thereby placing undue significance upon the 'Other' zone. In view of this and the fact that Africa is entirely absent from the list of zones, it is not surprising that virtually every operator qualifies for the 'Other' zone-the only exceptions are $\mathrm{O}_{2}$ and VimpelCom. Furthermore, of the 22, seven are to be found with a home base in the 'Anglo' zone (three in the USA, two in the UK and two in South Africa).

That said, it is of interest to note from Table 2 that only two operators achieve a psychic dispersion score above 50. The highest, at 80 per cent, is Hong Kong-based Hutchison Whampoa, but this is partly accounted for by its unique strategy of seeking to be a new entrant across a variety of zones via establishing third-generation (W-CDMA) rather than second-generation (GSM) networks. Close behind comes Vodafone with 70 per cent, although this appears to undervalue its international range of operations given that they include the likes of China and Egypt. ${ }^{12}$ In joint third place are France Télécom/Orange and

\footnotetext{
${ }^{12}$ Recent events suggest that any such undervaluation may not persist for much longer as, inter alia, Vodafone has sold its network in Japan and is under pressure to sell its minority stake in US-based Verizon Wireless.
} 
Table 2

Psychic dispersion (31 December 2005)

\begin{tabular}{|c|c|c|c|c|c|c|c|c|c|c|c|}
\hline & Total & Anglo & Germanic & Nordic & $\begin{array}{l}\text { Near } \\
\text { Eastern }\end{array}$ & Arab & $\begin{array}{l}\text { Far } \\
\text { Eastern }\end{array}$ & $\begin{array}{l}\text { Latin } \\
\text { American }\end{array}$ & $\begin{array}{l}\text { Latin } \\
\text { European }\end{array}$ & Independent & Other \\
\hline Hutchison Whampoa & 8 & $\mathrm{X}$ & $\mathrm{X}$ & $\mathrm{X}$ & & & $\mathrm{X}$ & $\mathrm{X}$ & $\mathrm{X}$ & $\mathrm{X}$ & $\mathrm{X}$ \\
\hline Vodafone & 7 & $\mathrm{X}$ & $\mathrm{X}$ & $\mathrm{X}$ & $\mathrm{X}$ & & & & $\mathrm{X}$ & $\mathrm{X}$ & $\mathrm{X}$ \\
\hline France Télécom & 5 & $\mathrm{X}$ & $\mathrm{X}$ & & & & $\mathrm{X}$ & & $\mathrm{X}$ & & $\mathrm{X}$ \\
\hline Telefónica & 5 & & & & & & $\mathrm{X}$ & $\mathrm{X}$ & $\mathrm{X}$ & $\mathrm{X}$ & $\mathrm{X}$ \\
\hline América Móvil & 4 & $\mathrm{X}$ & & & & & & $\mathrm{X}$ & & $\mathrm{X}$ & $\mathrm{X}$ \\
\hline Singapore Telecom & 4 & $\mathrm{X}$ & & & & & $\mathrm{X}$ & & & $\mathrm{X}$ & $\mathrm{X}$ \\
\hline Telecom Italia & 4 & & & & $\mathrm{x}$ & & & $\mathrm{X}$ & & $\mathrm{X}$ & $\mathrm{X}$ \\
\hline Telenor & 4 & & $\mathrm{X}$ & $\mathrm{X}$ & & & $\mathrm{X}$ & & & & $\mathrm{X}$ \\
\hline Verizon Comms & 3 & & & & & & & $\mathrm{X}$ & & $\mathrm{X}$ & $\mathrm{X}$ \\
\hline Deutsche Telekom & 3 & $\mathrm{X}$ & $\mathrm{X}$ & & & & & & & & $\mathrm{X}$ \\
\hline KPN & 3 & & $\mathrm{X}$ & & & & & & $\mathrm{X}$ & & $\mathrm{X}$ \\
\hline NTT & 3 & & & & & & $\mathrm{X}$ & & & $\mathrm{X}$ & $\mathrm{X}$ \\
\hline Orascom & 3 & & & & & & $\mathrm{X}$ & & & $\mathrm{X}$ & $\mathrm{X}$ \\
\hline Sprint Nextel & 3 & & & & & & & $\mathrm{X}$ & & $\mathrm{X}$ & $\mathrm{X}$ \\
\hline TeliaSonera & 3 & & & $\mathrm{X}$ & $\mathrm{X}$ & & & & & & $\mathrm{X}$ \\
\hline Alltel & 2 & & $\mathrm{X}$ & & & & & & & & $\mathrm{X}$ \\
\hline Etisalat & 2 & & & & & $\mathrm{X}$ & & & & & $\mathrm{X}$ \\
\hline MTC (incl. Celtel) & 2 & & & & & $\mathrm{X}$ & & & & & $\mathrm{X}$ \\
\hline $\mathrm{O}_{2}$ & 2 & $\mathrm{X}$ & $\mathrm{X}$ & & & & & & & & \\
\hline Portugal Telecom & 2 & & & & & & & & & $\mathrm{X}$ & $\mathrm{X}$ \\
\hline SK Telecom & 2 & & & & & & $\mathrm{X}$ & & & & $\mathrm{X}$ \\
\hline TDC & 2 & & $\mathrm{X}$ & & & & & & & & $\mathrm{X}$ \\
\hline Telekom Malaysia & 2 & & & & & & $\mathrm{X}$ & & & & $\mathrm{X}$ \\
\hline Tele2 & 2 & & & $\mathrm{X}$ & & & - & & & & $\mathrm{X}$ \\
\hline Investcom & 1 & & & & & & & & & & $\mathrm{X}$ \\
\hline Millicom & 1 & & & & & $C$ & & & & & $\mathrm{X}$ \\
\hline Mobile TeleSystems & 1 & & & & & & & & & & $\mathrm{X}$ \\
\hline MTN & 1 & & & & & & & & & & $\mathrm{X}$ \\
\hline OTE & 1 & & & & & 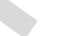 & & & & & $\mathrm{X}$ \\
\hline Telekom Austria & 1 & & & & & & & & & & $\mathrm{X}$ \\
\hline Turkcell Holding & 1 & & & & & & & & & & $\mathrm{X}$ \\
\hline Vivendi Universal & 1 & & & & & & & & & & $\mathrm{X}$ \\
\hline Vodacom & 1 & & & & & & & & & & $\mathrm{X}$ \\
\hline VimpelCom & 0 & & & & & & & & & & \\
\hline Total & 89 & 7 & 9 & 5 & 3 & 2 & 9 & 6 & 5 & 11 & 32 \\
\hline
\end{tabular}

Note: Anglo = Australia, Canada, Ireland, NZ, South Africa, UK, USA. Germanic = Austria, Germany, Switzerland. Nordic $=$ Denmark, Finland, Norway, Sweden. Near Eastern = Greece, Iran, Turkey. Arab = AbuDhabi, Bahrain, Kuwait, Oman, Saudi Arabia, UAE. Far Eastern = HK, Indonesia, Malaysia, Philippines, Singapore, S. Vietnam, Taiwan, Thailand. Latin European = Belgium, France, Italy, Portugal, Spain. Latin American = Argentina, Chile, Colombia, Mexico, Peru, Venezuela. Independent = Brazil, India, Israel, Japan. Other $=$ everywhere else.

Telefónica which score 50 per cent, but half of the scores are either 20 or 10 per centscores which, given the standard entry in the 'other' column, effectively mean that there is only a weak link with the previous work on psychic dispersion.

One factor reducing scores across the board is the virtual absence of entries in the 'Arab' zone. Only the two operators based in the zone, Etisalat of the UAE and MTC of Kuwait, have non-domestic networks there. This reflects the fact that the countries within the 'Arab' zone are either closed to foreign direct investment or are too small to attract the attention of an inward investor. There are also only three entries in the 'Near Eastern' zone although this is set to grow with liberalisation. It is of interest that of the eight operators with a psychic dispersion score of 40 per cent or more, the majority are present in the Anglo, Far Eastern and Independent zones respectively and half in the Germanic, Latin American and Latin European zones. Indeed, a surprising number of operators are present 
in at least one of the four countries that comprise the 'Independent' zone. Brazil and India in particular have attracted foreign investment because they are large emerging markets with substantial growth opportunities. The popularity of the 'Other' zone reflects the widespread liberalisation of the telecommunications industry in general and mobile in particular that has occurred in recent years. As a consequence, large swathes of Africa as well as parts of Eastern Europe and Asia are now open to foreign direct investment.

A final observation is that if we compare the number of countries identified in Table 1 with the psychic dispersion scores discussed above, a large country score does not necessarily equate into an equally high psychic dispersion score (although it is the case that three of the four operators with the highest dispersion scores are present in at least 25 countries). For example, KPN has a presence in three countries whereas TeliaSonera is present in 17. However, because each of the three investments by KPN is to be found in a different attitudinal zone while TeliaSonera has made multiple investments in the same zone, their psychic dispersion scores are the same.

\subsection{Number of proportionate subscribers}

Table 3 shows the number of proportionate subscribers controlled by each company. In addition, the table breaks down this figure by region. The table clearly highlights the large disparities that existed at the end of 2005 in terms of the number of proportionate subscribers controlled by each company, with the number controlled ranging from 179 million for Vodafone to under four million for Investcom. The 34 companies between them controlled roughly 1.135 billion proportionate subscribers. On the basis of the substantial variations that existed at the end of 2005, it is difficult to argue that internationalisation by mobile telecommunications companies is associated with any particular scale of operation.

Comparing the top 10 companies in Tables 1 and 3 is informative as several differences can be observed. In the first place, four of the 10 most-internationalised mobile telcos, as measured by country presence, are not included in the top ten when the measurement criterion changes to the number of proportionate subscribers. This feature would in practice have been much more pronounced had there been no minimum requirement placed upon the number of proportionate subscribers since Cable \& Wireless and Digicel operate in a large number of mostly small markets in the Caribbean.

Another company whose large geographical footprint is not reflected in its subscriber numbers is Hutchison Whampoa. This is because it does not own any of the heavily subscribed GSM networks in Western Europe having entered there fairly recently via the $3 \mathrm{G}$ licensing process. Conversely, there are two Russian operators and one American operator that have large numbers of subscribers but cover only a few markets. Again, it is worth observing that other major US-based operators such as BellSouth and SBC Communications (joint owners of Cingular Wireless) as well as Verizon Communications would have appeared in both columns in previous years but largely withdrew to their home market during 2005.

\subsection{Number and percentage of proportionate subscribers by region}

Table 4 re-works the data contained in Table 3 above so that the evident regional differences are highlighted. It is clear from the table that for many mobile operators their domestic market provided a significant number of their proportionate subscribers at the 
Table 3

Proportionate subscribers by region (31 December 2005)

\begin{tabular}{|c|c|c|c|c|c|c|c|c|}
\hline \multirow[t]{2}{*}{ Company } & \multirow{2}{*}{$\begin{array}{l}\text { Total } \\
\text { subs } \\
\text { (millions) }\end{array}$} & \multicolumn{7}{|c|}{ Number of subscribers by region ${ }^{\mathrm{a}}$ (millions) } \\
\hline & & $\begin{array}{l}\text { Western } \\
\text { Europe }\end{array}$ & $\begin{array}{l}\text { Eastern } \\
\text { Europe }\end{array}$ & $\begin{array}{l}\text { Middle } \\
\text { East }\end{array}$ & Asia & $\begin{array}{l}\text { Central and } \\
\text { South } \\
\text { America }\end{array}$ & $\begin{array}{l}\text { North } \\
\text { America }\end{array}$ & Africa \\
\hline Vodafone $^{\mathrm{b}}$ & 179.316 & 108.534 & 6.880 & - & 29.785 & - & 22.785 & 11.332 \\
\hline América Móvil & 92.635 & - & - & - & - & 86.611 & 6.024 & - \\
\hline Deutsche Telekom & 85.428 & 62.262 & 1.366 & - & - & - & 21.690 & 0.100 \\
\hline France Télécom ${ }^{\mathrm{c}}$ & 71.946 & 57.627 & 6.966 & 0.264 & 0.01 & 1.522 & $->$ & 5.555 \\
\hline Telefónica $^{\mathrm{d}}$ & 71.273 & 23.239 & - & - & 0.006 & 46.829 & - & 1.199 \\
\hline Mobile TeleSystems & 59.014 & - & 58.579 & - & 0.495 & - & - & - \\
\hline Telecom Italia & 49.525 & 28.576 & - & 2.179 & - & 18.790 & - & - \\
\hline Sprint Nextel & 44.780 & - & - & - & - & 0.493 & 44.287 & - \\
\hline VimpelCom & 44.305 & - & 43.355 & - & 0.950 & - & - & - \\
\hline Telenor & 42.599 & 7.293 & 21.064 & - & 14.242 & - & - & - \\
\hline Verizon Comms & 37.203 & 5.470 & - & - & - & 3.251 & 28.482 & - \\
\hline TeliaSonera & 35.778 & 12.370 & 10.353 & 11.498 & 1.262 & $\underline{1}$ & - & 0.295 \\
\hline NTT & 33.975 & - & - & - & 33.975 & - & - & - \\
\hline Singapore Telecom & 30.698 & - & - & - & 30.698 & - & - & - \\
\hline $\mathrm{O}_{2}$ & 27.417 & 27.417 & - & - & - & - & - & - \\
\hline Orascom & 24.624 & - & - & 0.894 & 14.218 & - & - & 9.512 \\
\hline KPN & 20.821 & 20.821 & - & - & - & - & - & - \\
\hline Vodacom & 20.123 & - & - & - & - & - & - & 20.123 \\
\hline SK Telecom & 19.423 & - & - & -0 & 19.423 & - & - & - \\
\hline MTN & 18.294 & - & - & -7 & - & - & - & 18.294 \\
\hline Hutchison Whampoa & 17.176 & 9.789 & - & 0.652 & 6.735 & - & - & 0.034 \\
\hline Portugal Telecom & 16.327 & 5.312 & - & 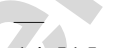 & 0.082 & 9.299 & - & 1.634 \\
\hline Turkcell Holding & 15.484 & - & 0.749 & 14.515 & 0.220 & & - & - \\
\hline Vivendi Universal & 14.351 & 9.300 & - & - & - & - & - & 5.051 \\
\hline Telekom Malaysia & 13.845 & - & - & - & 13.704 & - & - & 0.141 \\
\hline Alltel $^{\mathrm{e}}$ & 11.931 & 1.024 & - & - & - & 0.245 & 10.662 & - \\
\hline Tele $2^{\mathrm{f}}$ & 11.061 & 8.413 & 2.648 & - & - & - & - & - \\
\hline TDC & 10.026 & 9.987 & - & 0.039 & - & - & - & - \\
\hline MTC (incl. Celtel) & 9.340 & - & - & - & 4.010 & - & - & 5.330 \\
\hline Telekom Austria & 8.890 & 3.680 & 5.210 & - & - & - & - & - \\
\hline Millicom International & 6.992 & $-\infty$ & - & - & 2.330 & 3.022 & - & 1.640 \\
\hline OTE & 6.138 & 2.988 & 2.861 & 0.289 & - & - & - & - \\
\hline Etisalat & 5.733 & $-\infty$ & - & 5.315 & - & - & - & 0.418 \\
\hline Investcom & 3.751 & 0.065 & - & 1.452 & - & - & - & 2.234 \\
\hline
\end{tabular}

${ }^{\text {a }}$ Defined as per footnotes to Table 1 .

${ }^{b}$ Network Partnership Agreements are not included within Vodafone's total.

${ }^{\mathrm{c}}$ Those French overseas territories where Orange is present are counted separately and not included within France.

${ }^{\mathrm{d}}$ Total subscribers calculated through combining the proportionate subscribers derived from Telefónica's equity stake in Telefónica Móviles and then adding its own directly controlled subscribers to the total.

${ }^{\mathrm{e}}$ Including Western Wireless.

${ }^{\mathrm{f}}$ Tele 2 does not sufficiently separate its subscribers by country or line of business for an accurate breakdown of subscribers by country to be undertaken.

end of 2005, notwithstanding their internationalisation. For 14 of the companies listed, the home market accounted for at least half of the proportionate subscribers that they claimed, and for 10 among these the domestic market accounted for at least two-thirds of their 
Table 4

Percentage of proportionate subscribers by region (31 December 2005)

\begin{tabular}{|c|c|c|c|c|c|c|c|c|c|}
\hline \multirow[t]{2}{*}{ Company } & \multirow{2}{*}{$\begin{array}{l}\text { Total subs } \\
\text { (millions) }\end{array}$} & \multirow{2}{*}{$\begin{array}{l}\text { Domestic } \\
\text { as } \% \text { of } \\
\text { total }\end{array}$} & \multicolumn{7}{|c|}{ Percentage of subscribers by region ${ }^{\mathrm{a}}$} \\
\hline & & & $\begin{array}{l}\text { Western } \\
\text { Europe }\end{array}$ & $\begin{array}{l}\text { Eastern } \\
\text { Europe }\end{array}$ & $\begin{array}{l}\text { Middle } \\
\text { East }\end{array}$ & Asia & $\begin{array}{l}\text { Central } \\
\text { and South } \\
\text { America }\end{array}$ & $\begin{array}{l}\text { North } \\
\text { America }\end{array}$ & Africa \\
\hline SK Telecom & 19.423 & 99.4 & - & - & - & 100 & - & - & - \\
\hline Sprint Nextel & 44.780 & 98.5 & - & - & - & - & 1.1 & 98.9 & - \\
\hline VimpelCom & 44.305 & 97.2 & - & 97.9 & - & 2.1 & - & - & - \\
\hline Turkcell Holding & 15.484 & 91.9 & - & 4.8 & 93.8 & 1.4 & - & - & - \\
\hline Alltel $^{\mathrm{b}}$ & 11.931 & 89.4 & 8.5 & - & - & - & 2.1 & 89.4 & - \\
\hline Vodacom & 20.123 & 87.5 & - & - & - & - & - & - & 100 \\
\hline NTT & 33.975 & 86.1 & - & - & - & 100 & $\perp$ & - & - \\
\hline Etisalat & 5.733 & 78.5 & - & - & 92.7 & - & - & - & 7.3 \\
\hline Verizon Comms & 37.203 & 75.9 & 14.8 & - & - & - & 8.7 & 76.5 & - \\
\hline Mobile TeleSystems & 59.074 & 74.9 & - & 99.3 & - & 0.7 & - & - & - \\
\hline Vivendi Universal & 14.351 & 64.8 & 64.8 & - & - & - & - & - & 35.2 \\
\hline $\mathrm{O}_{2}$ & 27.417 & 58.3 & 100 & - & - & $\underline{-1}$ & - & - & - \\
\hline Telecom Italia & 49.545 & 57.6 & 57.6 & - & 4.4 & - & 38.0 & - & - \\
\hline $\mathrm{MTN}^{\mathrm{c}}$ & 18.294 & 51.9 & - & - & - & - & - & - & 100 \\
\hline Telekom Malaysia & 13.845 & 49.5 & - & - & - & 99.0 & - & - & 1.0 \\
\hline OTE & 6.138 & 48.7 & 48.7 & 46.6 & 4.7 & - & - & - & - \\
\hline América Móvil & 92.635 & 38.8 & - & - & - & - & 93.5 & 6.5 & - \\
\hline KPN & 20.821 & 38.8 & 100 & - & - & - & - & - & - \\
\hline Telekom Austria & 8.890 & 37.6 & 41.4 & 58.6 & - & - & - & - & - \\
\hline Deutsche Telekom & 85.428 & 34.4 & 72.9 & 1.6 & - & - & - & 25.4 & 0.1 \\
\hline Portugal Telecom & 16.327 & 32.5 & 32.5 & - & - & 0.5 & 57.0 & - & 10.0 \\
\hline France Télécom ${ }^{\mathrm{d}}$ & 71.426 & 31.4 & 80.0 & 9.7 & 0.4 & 0.1 & 2.1 & - & 7.7 \\
\hline Tele $2^{\mathrm{e}}$ & 11.061 & 28.0 & 76.1 & 23.9 & - & - & - & - & - \\
\hline Telefónica & 71.273 & 25.8 & 32.6 & - & - & 0.1 & 65.6 & - & 1.7 \\
\hline $\mathrm{TDC}$ & 10.026 & 25.3 & 99.6 & - & 0.4 & - & - & - & - \\
\hline TeliaSonera $^{\mathrm{f}}$ & 35.778 & 19.3 & 34.6 & 28.9 & 32.3 & 3.5 & - & - & 0.8 \\
\hline MTC $^{\mathrm{g}}$ (incl. Celtel) & 9.340 & 15.4 & - & - & 42.9 & - & - & - & 57.1 \\
\hline Vodafone $^{\mathrm{h}}$ & 179.316 & 9.1 & 60.6 & 3.8 & - & 16.6 & - & 12.7 & 6.3 \\
\hline Orascom $^{\mathrm{i}}$ & 24.624 & 8.4 & - & - & 3.6 & 57.7 & - & - & 38.7 \\
\hline Telenor & 42.599 & 6.4 & 17.1 & 49.4 & - & 33.5 & - & - & - \\
\hline Singapore Telecom & 30.698 & 5.3 & - & - & - & 100 & - & - & - \\
\hline Hutchison Whampoa & 17.176 & 4.0 & 57.0 & - & 3.8 & 39.1 & - & - & 0.1 \\
\hline Investcom $^{\mathrm{j}}$ & 3.751 & 0.0 & 1.7 & - & 38.7 & - & - & - & 59.6 \\
\hline Millicom Int ${ }^{\mathrm{k}}$ & 6.992 & 0.0 & - & - & - & 33.3 & 43.2 & - & 23.5 \\
\hline
\end{tabular}

${ }^{\text {a }}$ Defined as per footnotes to Table 1.

b The company's home market is the USA.

'The company's home market is South Africa.

${ }^{\mathrm{d}}$ Those French overseas territories where Orange is present are counted separately and not included within France.

${ }^{\mathrm{e}}$ Tele2 does not sufficiently separate its subscribers by country or line of business for an accurate breakdown of subscribers by country to be undertaken.

f TeliaSonera's home market is defined as Finland plus Sweden.

${ }^{g}$ Mobile Telecommunications Co.'s home market is Kuwait while Celtel is based in the Netherlands.

${ }^{\mathrm{h}}$ The company's home market is Egypt.

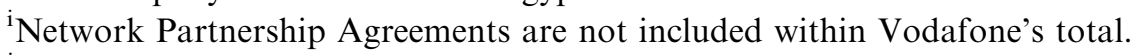

${ }^{\mathrm{j}}$ The company is based in Lebanon and listed in Dubai.

${ }^{\mathrm{k}}$ The company's home market is Luxembourg. 
proportionate subscribers. There were even four operators whose domestic market provided more than 90 per cent of their proportionate subscribers, while at the other end of the spectrum there were two operators that did not operate at all in what was technically their domestic market.

If we remove these two operators from consideration, then Hutchison Whampoa, Singapore Telecom, Telenor, Orascom and Vodafone stand out as their domestic markets account for less than 10 per cent of their proportionate subscriber base. In the case of Hutchison Whampoa, Telenor, and especially of Singapore Telecom, this simply reflects the small size of their domestic markets, but this is clearly not the case for Vodafone in the United Kingdom. The UK accounts for 9 per cent of Vodafone's proportionate subscribers, with the remainder being spread across the rest of Western Europe (51.5 per cent), Asia (16.6 per cent), North America (12.7 per cent), Africa (6.3 per cent) and Eastern Europe (3.8 per cent). While this does demonstrate that Western Europe provides the majority of Vodafone's proportionate subscribers, it also shows that Vodafone has a substantive presence in at least two other regions, namely Asia and North America. Vodafone's presence in a further region, Africa, was superficially quite small, but this fails fully to reflect its 35 per cent stake in Vodacom of South Africa-raised to 50 per cent in January 2006 - which is growing rapidly.

Through an examination of the percentage of proportionate subscribers by region, we can conclude that many mobile operators are in fact highly regional in their international focus. For 20 out of the 34 companies detailed in Table 4, one region accounted for at least two-thirds of their proportionate subscribers as follows:

- Western Europe: Deutsche Telekom, France Télécom, KPN, $\mathrm{O}_{2}$, TDC and Tele2.

- Eastern Europe: Mobile TeleSystems and VimpelCom.

- Middle East: Etisalat and Turkcell Holding.

- Asia: NTT, Singapore Telecom, SK Telekom and Telekom Malaysia.

- Central and South America: América Móvil

- North America: Alltel, Sprint Nextel and Verizon Communications.

- Africa: MTN and Vodacom.

In every case, this region was also where they were headquartered.

A further issue to address is whether, if a large number of mobile operators draw their proportionate subscribers predominantly from a single region, any of them had a significant presence in two or more regions. If drawing 20 per cent of the proportionate subscriber base from a single region is taken as being a significant presence, then 15 operators had a significant presence in two or more regions at the end of 2005. Those operators with such a presence were Deutsche Telekom, Hutchison Whampoa, Investcom, Millicom International, MTC, Orascom, OTE, Portugal Telecom, Telekom Austria, Telecom Italia, Telefónica, Telenor, TeliaSonera, Tele2 and Vivendi Universal. Only Millicom International and TeliaSonera among these had a significant presence in three regions. However, for eleven of these operators a single region, which more often than not was their domestic region, still provided more than half of their subscribers. It is also of interest to note that Portugal Telecom and Telefónica drew more than half of their proportionate subscribers from Central and South America and only one-third from their domestic region. 


\section{Identifying the most internationalised operators}

In the previous section certain important dimensions of internationalisation have been explored. As a part of this, attention has been drawn to the fact that the list of the ten most internationalised mobile telcos as determined by the number of countries in which they were present at the end of 2005 was not the same when the number of proportionate subscribers was the measurement criterion. This was also the case when the percentage of proportionate subscribers outside the mobile operator's domestic market was used.

Table 5 lists the top 10 operators according to the various criteria discussed above. Drawing on Table 5, it is possible to identify three mobile operators that appear among the top ten companies on all of the criteria, namely Telefónica, Telenor and Vodafone while América Móvil, Deutsche Telekom, France Télécom, Hutchison Whampoa, Orascom and TeliaSonera appear in three columns. The first observation that we can make is that since Vodafone has a higher ranking than Telefónica and Telenor on four and three of the criteria, respectively, it must be deemed to have been the most internationalised operator in the mobile telecommunications sector during 2005. Nevertheless, with roughly 60 per cent of its subscribers coming from the West European region, no subscribers at all in two of the seven regions, a now much reduced presence in Asia and with negotiations ongoing to sell out in the USA, it nevertheless takes something of a leap of imagination before Vodafone can be deemed to be a truly world-wide operator.

The rank order beyond Vodafone is rather more contentious. Whereas Telefónica is not overly dependent upon its home market, it effectively operates in only two regions with Spain providing the great bulk of its European subscribers and Brazil the bulk of the remainder. Hence, while it has recently been actively seeking to expand its horizons, especially with the purchase of $\mathrm{O}_{2}$, its profile remains bi-regional. Meanwhile Telenor is a

Table 5

The most-internationalised mobile operators at 31 December $2005^{\mathrm{a}}$

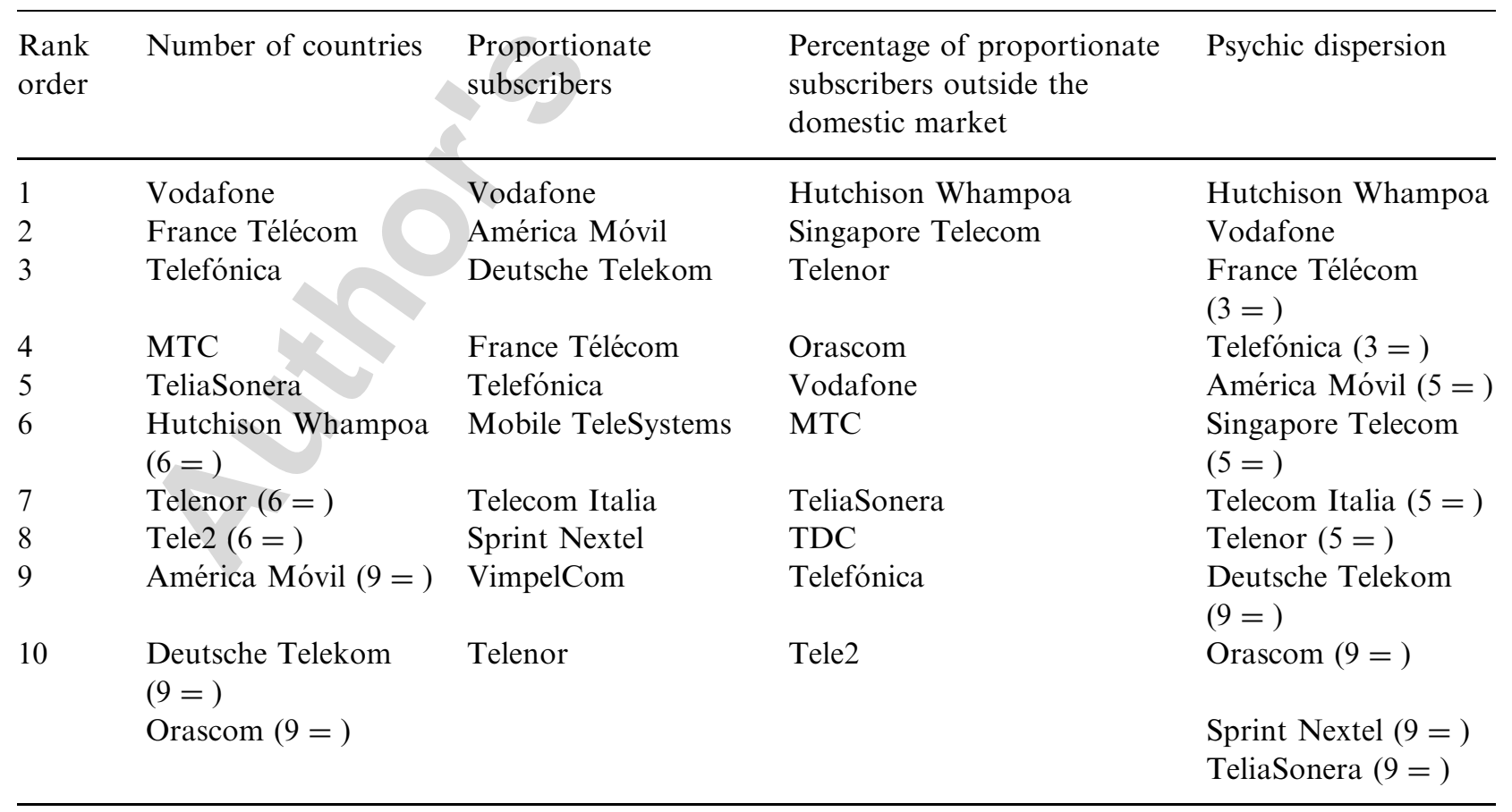

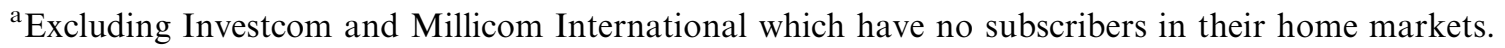


much smaller operation and only operates in three regions, so its appearance in all four columns is deceptive. Clearly, although not bi-regional, it is not far off that description given the proximity of its West and East European investments.

For its part, France Télécom is present in six regions, which would be an impressive result were it not for the fact that it is so dependent upon a single region for its subscribers (and hence fails to make the list in column three). As an aspiring world-wide operator it has much to thank for its colonial past, but in subscriber terms it is really tri-regional with no presence in North America and only rather minor networks in several other regions. Furthermore, it is unlikely to make major new investments in the near future. América Móvil appears in the same three columns, which is impressive for an operator based in Latin America, but it is effectively a one-region operator with a big domestic market, so once again its multiple appearances in Table 5 are deceptive. That leaves Hutchison Whampoa, a company whose telecommunications holdings are undergoing radical restructuring. These holdings are growing rapidly due to the long-awaited explosion of $3 \mathrm{G}$ subscriptions, mainly in Italy and the UK. However, needing to fund its huge investments in $3 \mathrm{G}$, and having hived off most of its non-European assets into Hutchison Telecom International (HTIL), it subsequently sold a fifth of HTIL to Orascom and hopes to conduct IPOs in India, Italy and the UK. At the end of the day, therefore, its position in Table 5 is somewhat deceptive because its domestic market is so small and it remains essentially a bi-regional operator, albeit one with a much more laid-back attitude than other operators about moving into markets where it has little psychic affinity.

The fact that two major West European incumbents, Deutsche Telekom and Telecom Italia, are less prominent may be viewed as surprising. In the latter case, however, this reflects a conscious strategy of concentrating upon the very large markets of Italy, Brazil (where it now intends to sell out) and Turkey while selling its non-core networks. Deutsche Telekom is a more interesting case because it has recently exited the high-growth market of Russia, declined to bid for $\mathrm{O}_{2}$ and its CEO stated in August 2005 that it was "not actively seeking new acquisitions, but we will continue to evaluate new opportunities which arise within our existing footprint'. ${ }^{13}$ Clearly, this is hardly the profile of a company with global ambitions. Finally, TeliaSonera, the only European operator that was the product of a merger, performs well and only just fails to qualify in all four columns. However, although it has operations in a commendable five regions, its subscribers are almost equally divided between just three of them so it is clearly a classic tri-regional operator.

\section{Conclusions}

It is first necessary to comment on the database employed above. There is, in principle, a case to be made for also including financial measures of internationalisation. However, it has been possible to analyse 34 companies in this paper and if financial measures were to be included the sample would be substantially reduced both in total and geographic spread as not all of the sample companies publish data at the required level of detail. This is also true of those measures that look at, for example, the proportion of domestic to total employees. While the inclusion of such measures would further our understanding of internationalisation in the mobile sector, it would do so at the expensive of comprehensiveness. In other words, our understanding of internationalisation would be

\footnotetext{
${ }^{13}$ See http://www.cellular-news.com of 11 August 2005.
} 
furthered in a limited number of cases - predominantly based in Europe and the USA - at the expense of not being able to discern broader trends within the industry. The need to include financial measures of internationalisation would, for example, exclude many of the mobile operators based in the Middle East and Africa and, as a consequence, the emergence of a new type of internationalising mobile operator, namely, one based in a developing country and investing in other developing countries, would be downplayed or perhaps even overlooked altogether.

Secondly, it may be noted that no attempt has been made to calculate a single measure of internationalisation even though, in principle, it would be possible to meld together the rankings shown in Table 5. A composite index could be constructed that equally weights the four dimensions of internationalisation that have been discussed. A numerical value is given to each company equal to its rank in the table, with a lower value equating to a greater degree of internationalisation. If such an approach is adopted, the resulting index identifies Vodafone as the most internationalised operator. However, as two subscriber dimensions are included in the index a better approach may be to equally weight country presence, psychic dispersion and subscribers. Again, the lower the score the greater is the degree of operator internationalisation. Recalculating the index on this basis confirms Vodafone as the most-internationalised operator, with the gap between Vodafone and France Télécom, the second-most-internationalised, being more or less the same as in the first index. Alternatively, it may be more appropriate to weight country presence as being more important than subscribers, which, in turn, is more important than psychic dispersion. ${ }^{14}$ Psychic dispersion is given the least weight in the index to reflect its lack of geographical coverage when compared to those countries that now allow some form of foreign direct investment in their mobile telecommunications industries. Recalculating the index produces much the same results although the gap between France Télécom and Vodafone is less than in the previous two cases.

The gap between Vodafone and France Télécom fluctuates because the weights pick up the respective strengths of the two companies. The three sets of weights noted above are arguably equally valid insofar that they reflect different understandings of internationalisation. The ability to suggest alternative weights, or to critique the three suggestions made, requires a detailed understanding of the telecommunications industry. This is also true for the data collection that underpins the various dimensions of internationalisation. As the construction of a sector-specific index requires a high degree of specialised knowledge, problems may arise in both its development and subsequent use. In other words, the replication of a sector-specific index is not straightforward even when the relatively simple measures of internationalisation adopted here are used. The inclusion of additional dimensions is likely to serve only to complicate the data collection and index construction process.

Having said this, it is possible to include additional dimensions into the analysis through techniques such as factor analysis. Hassel et al. (2003) apply such a technique to their sample of German multinationals, though they argue that the 'real' and financial indices that they construct measure distinct aspects of internationalisation. ${ }^{15}$ Moreover, they

\footnotetext{
${ }^{14}$ The index is weighted as follows 40 per cent country presence, 35 per cent to an average of proportionate subscribers and proportionate subscribers by region and 25 per cent to psychic dispersion.

${ }^{15}$ According to Hassel et al. (2003, p. 711), 'real' dimensions of internationalisation include sales, assets and employees.
} 
conclude that combining such indices together into a single measure of internationalisation would distort any ranking that emerges. As the financial rewards from internationalisation in telecommunications are dependent on first acquiring a country presence and then proportionate subscribers, they are not aligned in time. That is, there is a generally lengthy lag between entering the market via a licence acquisition or, indeed, via a takeover (because of regulatory issues) and the accruing of financial rewards. Thus, a single measure would under- or over-emphasise internationalisation depending upon how the lag is incorporated into the index.

Despite these reservations, the study has led to some interesting conclusions. It is often claimed that telecommunications is a global industry in the sense that companies operating within it have a global presence. Through examining the degree to which internationalisation within the mobile telecommunications sector has occurred, this paper challenges such an assertion. Close examination of individual operators demonstrates that most are biregional at best and that even Vodafone cannot claim to have a world-wide presence other than in the limited sense of coverage via roaming agreements.

The fact is that even experienced operators like Vodafone have struggled in some mobile telecommunication markets. The range of uncertainties that mobile operators face is highlighted by Sanchez-Peinado and Pla-Barber (2006), who identify three broad uncertainty categories: host country, demand and behaviour. In Japan, Vodafone struggled to understand the market. In part, this was because senior management were drawn from outside the country with the consequence that they did not fully understand the market, and in part because Vodafone was also present in the less familiar fixed telecommunications market. In addition, Vodafone also failed to appreciate some of the technological characteristics of the market. This was particularly evident in respect of handsets; Vodafone's attempt to introduce European-style handsets proved to be unpopular with consumers and resulted in it losing market share to its rivals (Williams, 2006). Thus, there are clear limits to the standardisation of information and communication technology products to which Gabrielsson and Gabrielsson (2004) draw attention.

Vodafone's foray into Japan vividly illustrates that what works in one market may not work in another. Vodafone has implicitly acknowledged the differences that exist between markets by highlighting a set of core European markets - Germany, Italy, Spain and the UK. The challenge for Vodafone in these markets is to increase the revenue that it extracts from each subscriber, whereas the challenge in markets where the level of mobile uptake is much less, such as those in Africa or India, is to grow its subscriber base. One way through which Vodafone may increase revenues in its core European markets is through improved co-ordination of its national subsidiaries so that, for example, best practice is transferred from one market to another. There is undoubtedly some co-ordination across Europe; for example, common services have been introduced, although at present it is not clear whether or not this has led to improved financial results. The use of a common brand may also have encouraged roaming, a traditionally lucrative source of revenue, but this has come under investigation by the European Union in recent months (Laitner, 2006; Vodafone, 2006). The challenges that Vodafone faces have stretched its management team to the full, which, when coupled with apparent internal differences has led some shareholders to call for change (Edgecliffe-Johnson \& Burgess, 2006).

Managerial disagreements within telecommunications companies are nothing new. Many of these stay behind closed doors, with only a handful coming into the public domain like those at Vodafone. More common are disputes between joint venture 
shareholders such as that at VimpleCom, where major shareholders Telenor and Alfa differ over the strategy to be adopted. Tensions between the two shareholders have been inflamed by alleged conflicts of interest on the part of Alfa, whose influence on the VimpelCom board has also led to a decline in its corporate governance rating (Telenor, 2006). A failure to resolve these differences could see Telenor sell one or more of its Eastern European networks, which given that they collectively account for half of all its proportionate subscribers would represent a substantial change in strategy on its part. However, this should not be taken as suggesting that disputes only occur between companies originating from countries that are culturally quite distant. Although Telenor (Norway) and Telia (Sweden) are based in countries that are culturally close, cultural factors did contribute to their failure to agree on merger terms (Fang et al., 2004).

The analysis has also highlighted that really acquisitive operators appear to be emerging - and this is a very recent phenomenon-from the Middle East and Russia. There are arguably parallels with the international expansion of US-based operators in the 1990 s, but if so the auguries are not too good. MTC, for example, has stated that it is pursuing a ' $3 \times 3 \times 3$ ' strategy - a 9-year, three-phase plan that will see it progress from being a regional to international and ultimately global operator. However, acquiring a relatively small regional specialist such as Celtel is not a strategy that can be repeated as a route to global status and there is the issue, as Etisalat found when over-bidding for Pakistan's PTCL, of affording such a strategy even for those with oil riches and domestic monopolies. It may be noted that no Chinese operators are included in our sample, primarily because they have devoted their energies so far exclusively to their domestic market and also because, as was demonstrated when China Mobile tried unsuccessfully to acquire Millicom International (Guerrera \& Reed, 2006), they are not necessarily welcome.

Faced with this new phenomenon, managers in countries that have traditionally provided the impetus towards internationalizing the sector must decide whether to compete or not. In practice, this is not much of a choice either because domestic exigencies are dictating strategies - such as in the USA where domestic restructuring is absorbing all available management time and one obvious way to raise the requisite capital is to sell noncore holdings overseas - or because the financial markets are unwilling to finance new international adventures.

It is somewhat ironic that this is happening at precisely the point in time when balance sheets have been restored to order after the meltdown of 2002 and 2003, but management would do well not to repeat the 'growth is good' mantra of the late 1990s. By and large, a solid, defensive and inward-looking operation is what the financial markets currently favour, at least until the implications of many of the new threats/opportunities such as fixed-mobile convergence, mobile TV and voice over Internet protocol (VoIP) have worked their way through the system. However, it must be acknowledged that since the threats are initially impacting fixed-wire operations, the temptation to compensate by seeking to acquire additional mobile holdings despite inflated prices is going to remain a temptation for some time to come.

Finally, drawing on the reservations noted above, it is possible to suggest two areas for further research. One such area is that of psychic dispersion and how it can be implemented so that the widespread liberalisation of telecommunications that has occurred is reflected in the countries covered by the measure. At the moment, too many countries fall into the 'Other' category with the consequence that the degree of internationalisation is misrepresented. Geographical coverage could be broadened through applying the 
suggestions made in Shenkar (2001). A second area of further research is to identify which financial measures are available across the industry. The substantial variation that presently exists in financial reporting between countries, limits the extent to which financial criteria can be included in any index. While fewer companies could be included in the index, this does limit the degree to which observations can be made regarding internationalisation at the sector level. Thus, further research should attempt to identify an appropriate financial measure that can be used across the sector.

\section{References}

Bevan, A., Estrin, S., \& Meyer, K. (2004). Foreign investment location and institutional development in transition economies. International Business Review, 13(1), 43-64.

Braithwaite, J., \& Drahos, P. (2000). Global business regulation. Cambridge, England: Cambridge University Press.

Chan-Olmsted, S., \& Jamison, M. (2001). Rivalry through alliances: Competitive strategy in the global telecommunications market. European Management Journal, 19(3), 317-331.

Curwen, P. (2005). A brief illustrated discourse on the concept of 'large' in the context of mobile telephony. Info, 7(1), 76-82.

Curwen, P., \& Whalley, J. (2004). Telecommunications strategy. Cases, theory and applications. London, England: Routledge.

Daßler, T., Parker, D., \& Saal, D. (2002). Economic performance in European telecommunications, 1978-1998: A comparative study. European Business Review, 14(3), 194-209.

Dörrenbacher, C. (2000). Measuring corporate internationalisation-A review of measurement concepts and their use. Intereconomics, 35(3), 119-126.

Dunning, J. H. (1993). Multinational enterprises and the global economy. Wokingham, England: Addison-Wesley Publishing Company.

Edgecliffe-Johnson, A. \& Burgess, K. (2006). Vodafone directors facing backlash, available at <http:// news.ft.com $>$ of 4 June.

Fang, T., Fridh, C., \& Schultzberg, S. (2004). Why did the Telia-Telenor merger fail? International Business Review, 13(5), 573-594.

Gabrielsson, P., \& Gabrielsson, M. (2004). Globalizing internationals: Business portfolio and marketing strategies in the ICT field. International Business Review, 13(6), 661-684.

Gerpott, T., \& Jakopin, N. (2005). The degree of internationalization and the financial performance of European mobile network operators. Telecommunications Policy, 29, 635-661.

Guerrera, F., \& Reed, J. (2006). Millicom set to be bought by China mobile, available at $\langle$ http://news.ft.com $\rangle$ of 2 May.

Hassel, A., Höpner, M., Kurdelbusch, A., Rehder, R., \& Zugehör, R. (2003). Two dimensions of the internationalisation of firms. Journal of Management Studies, 40(3), 705-723.

Hofstede, G. (1980). Culture's consequences: International differences in work-related values. Beverley Hills, California: SAGE Publications.

Ietto-Gillies, G. (1998). Different conceptual frameworks for the assessment of the degree of internationalization: An empirical analysis of various indices for the top 100 transnational corporations. Transnational Corporations, 7(1), 17-39.

International Telecommunications Union. (2003). World telecommunications development report-Access Indicators for the Information Society, ITU: Geneva, Switzerland.

International Telecommunications Union. (2006). Trends in telecommunications reform 2006. Geneva, Switzerland: Regulating in the Broadband World, ITU.

Johanson, J., \& Vahlne, J.-E. (1977). The internationalisation process of the firm-a model of knowledge development and increasing foreign commitments. Journal of International Business Studies, 8(1), $23-32$.

Kogut, B., \& Singh, H. (1988). The effect of national culture on the choice of entry mode. Journal of International Business Studies, 19, 411-432.

Laitner, S. (2006). EU set to ban mobile phone roaming charges, available at $\langle$ http://news.ft.com $\rangle$ of 8 May. Manner, J. A. (2002). Global telecommunications market access. Boston, Mass: Artech House Publications. 
Perlmutter, H. V. (1969). The tortuous evolution of the multinational corporation. Columbia Journal of World Business, IV(1), 9-18.

Ramaswamy, K., Kroeck, K., \& Renforth, W. (1996). Measuring the degree of internationalisation of a firm: A comment. Journal of International Business Studies, 27(1), 167-177.

Ronen, S., \& Shenkar, O. (1985). Clustering countries on attitudinal dimensions: A review and synthesis. Academy of Management Review, 10(3), 435-454.

Root, F. R. (1987). Entry strategies for international markets. Lexington, MA: D.C. Heath and Company.

Rugman, A. (2005). The regional multinationals. Cambridge, England: Cambridge University Press.

Sanchez-Peinado, E., \& Pla-Barber, J. (2006). A multidimensional concept of uncertainty and its influence on the entry mode choice: An empirical analysis in the service sector. International Business Review, 15(3), $215-232$.

Sarkar, M., Cavusgil, S., \& Aulakh, P. (1999). International expansion of telecommunication carriers: The influence of market structure, network characteristics and entry imperfections. Journal of International Business Studies, 30(2), 361-382.

Shenkar, O. (2001). Cultural distance revisited: Towards a more rigorous conceptualization and measurement of cultural differences. Journal of International Business Studies, 32(3), 519-535.

Smith, A., \& Zeithaml, C. (1998). Garbage cans and advancing hypercompetition: The creation and exploitation of new capabilities and strategic flexibility in two regional Bell operating companies. In A. Y. Ilinitch, A. Y. Lewin, \& R. D'Aveni (Eds.), Managing in times of disorder. Hypercompetitive organisational responses. Thousand Oaks, CA: SAGE Publications.

Steinbock, D. (2002). Wireless horizon. New York: Amacom.

Steinbock, D. (2005). The mobile revolution. London: Kogan Page.

Sullivan, D. (1994). Measuring the degree of internationalization of a firm. Journal of International Business Studies, 25(2), 325-342.

Sullivan, D. (1996). Measuring the degree of internationalisation of a firm: A reply. Journal of International Business Studies, 27(1), 179-192.

Telenor (2006). The future direction of Vimpelcom is at stake at the AGM. Do not be misled by Alfa/Altimo, 14 June, available at 〈www.telenor.com $\rangle$.

UNCTAD. (2005). World investment report 2005-transnational corporations and the internationalisation of R\&D. New York and Geneva: UNCTAD.

Vodafone (2006). Vodafone to reduce the cost of European roaming by at least $40 \%$ by April 2007, press release issued on 8 May.

Walden, I., \& Angel, J. (2005). Telecommunications law and regulation (2nd ed.). Oxford, England: Oxford University Press.

Williams, M. (2006). Vodafone in talks to sell struggling Japan unit. InfoWorld, 6 March, available at < http:// www.infoworld.com $>$.

Zacher, M. (1996). Governing global networks. Cambridge, England: Cambridge University Press. 